\title{
NATIONAL INNOVATION SYSTEM DEVELOPMENT: EVIDENCE FROM THE COUNTRIES OF THE CENTRAL AND EASTERN EUROPE REGION
}

\section{Vasylchenko Mariana ${ }^{1}$ \\ Khrystenko Olena ${ }^{2}$}

DOI: http://dx.doi.org/10.30525/978-9934-571-28-2_6

\begin{abstract}
The given paper is dedicated to the determination of the theoretical aspects of a national innovation system as an analytical tool to evaluate the technological development of any country. The notion of the term "national innovation system" (NIS) is considered by authors. It is emphasized that the concept of NIS became widely used in the last decade of the $\mathrm{XX}$ century due to an intensification of interest in studying of how the relationships among industries, various research and development institutions, government bodies and academia could be harnessed to sustain innovation initiatives at micro and macro level. It is proved that the innovation capability of each country greatly depends on the efficiency of its national innovation system. The findings of the analysis indicate that in many cases such a system requires the generation and dissemination of knowledge, along with the utilization of innovation. Consi-derable attention is given to the analysis of the available experience of the countries of the Central and Eastern Europe region in this field.
\end{abstract}

Therefore, the main purpose of the given paper is to put everyone in the picture about the economic essence of the concept of a national innovation system, to analyze the national innovation systems in the Central and Eastern Europe as a region, which is trying to find its identity in the present-day context, and to determine potential policy options for improving the innovation capacity of Ukraine. The methodology has been designed through a critical literature review. The study is descriptive and analytical in nature, because the relevant publications were consulted to

\footnotetext{
${ }^{1}$ Candidate of Economic Sciences, Associate Professor,

Associate Professor of the Department of Management and Logistics,

Poltava National Technical Yuri Kondratyuk University, Ukraine

${ }^{2}$ Candidate of Economic Sciences,

Associate Professor of the Department of Management and Logistics,

Poltava National Technical Yuri Kondratyuk University, Ukraine
} 
investigate the changing concepts of a national innovation system in the world and to identify the best practices of the innovation management in the countries of the Central and Eastern Europe region in order to determine the contemporary approach to the innovation system development in Ukraine.

The findings of the analysis indicate that on the one hand, there are low indexes of competitiveness of the national economy and the readiness of Ukraine to function in the global market. On the other hand, in many fields of scientific research and innovation the priority positions of the country remain competitive. Consequently, it should be emphasized that the implementation of the integrated approach in promoting innovative initiatives is expedient in Ukraine.

\section{Introduction}

In the present-day context, innovations still remain critical to the success of businesses in the global trading system. The development of ideas into some con-structive goods and services further results in increase of the consumer interest and demand. As a result, millions of new jobs are created, national economies continue to grow and advanced societies still advance.

Each region or part of "the world chessboard" has its own driving and restraining factors of innovation engagement. For a long period of time, Europe was considered to be the main knowledge production centre in the global economy, "accounting for one-third of the world's science and technology production" [1]. But during the last five years, the authorized experts have been highlighted the fact that "Europe's research and innovation performance has declined, causing a broadening of the already sizeable innovation gap with US and Japan" [2]. And, finally, "Asia has for the first time overtaken Europe in its number of innovation centers built and operated with the region now host to nearly a third (29\%) of all such centers globally. So strong is Asia's growth that it could soon overtake the US as the biggest hub of innovation centers, if it continues to grow at the same rate" [1]. Consequently, "Europe and its policymakers must become more open to innovation and new technologies. Moreover, this region should embrace the many opportunities and manage the respective risks rather than banning or restricting technologies pre-emptively" [3, p. 3].

According to the last official edition of the "European Innovation Scoreboard 2017" [4, p. 14], which releases the information on the 
comparative analysis of innovation performance in the EU region and addresses the core strengths and weaknesses of the existing national innovation systems, all the countries of the EU can be grouped into the following performance groups: innovation leaders (Denmark, Finland, Germany, the Netherlands, Sweden and the United Kingdom), whose performance is more than $20 \%$ above the average level of the EU; strong innovators (Austria, Belgium, France, Ireland, Luxembourg, and Slovenia) with a total performance between $90 \%$ and $120 \%$ of the EU average; moderate innovators (Croatia, Cyprus, the Czech Republic, Estonia, Greece, Hungary, Italy, Latvia, Lithuania, Malta, Poland, Portugal, Slovakia and Spain), whose performance is estimated between $50 \%$ and $90 \%$ of the EU average; modest innovators (Bulgaria and Romania only), with a performance below $50 \%$ of the EU average level.

Obviously, all the above-mentioned groups of the EU countries tend to be geographically concentrated. The most innovative countries in Europe "are surrounded by different zones of countries and their average performance decreases with increasing geographical distance from the recognized innovation leaders" [4, p. 14].

That is why the overall purpose of this paper is to put everyone in the picture about the economic essence of the concept of a national innovation system, to analyze the national innovation systems in the Central and Eastern Europe as a region, which is trying to find its identity following the breakdown of the Soviet Union almost three decades ago, and to determine potential policy options for improving the innovation capacity of Ukraine.

The design of the study consists of four main steps, namely: an overview of the changing concepts of national innovation systems in the world; determination of the challenges facing the national innovation system development in the countries of the Central and Eastern Europe region; analysis of the possibility of implementation of the integrated innovation approach in Ukraine.

Within the present study we understand that there are many different ways that research could be done. However, what all research has in common is that it embraces a sequence or set of activities that are highly interrelated and that together generate the research process. Various studies have found that the ordinary activities in the research process usually follow a straight order, but it's quite possible to describe and explain the common pattern. The research is a flexible cyclical process, because the main 


\section{National innovation system development: evidence from the countries of...}

research findings often create new issues and ideas that need to be further investigated.

This study builds on primary and secondary data sources. The study has been developed through a critical review of literature related to national innovation systems all over the world. The information is derived from the reputable paper-based and electronic information sources, such as wellknown academic journals and official reports. The literature review has enabled an analysis of the key challenges to national innovation system development in the countries of Central and Eastern Europe region and has facilitated the identification of the approach to develop innovation engagement in Ukraine.

\section{Changing concepts of national innovation systems in the world}

The concept of a national innovation system was initially put forward as a qualitative concept for describing the technological, economic, social and institutional dimensions of innovation in advanced economies [5]. As Ramanathan K. [6] states, the interest in NIS came about because experience suggested that in the economically advanced countries of Europe, North America and Asia, government research institutes, universities and the industries worked in collaboration to promote innovation at the micro level and thus spur economic development. The role that the state governments played in stimulating such collaboration attracted interest in many countries.

The desire to understand this global phenomenon better, led us to consider the origins of a national innovation system. This term was first coined in 1980s by C. Freeman, who defined it as "the network of institutions in the public and private sectors whose activities and interactions initiate, import, modify and diffuse new technologies" [7] and B.-A. Lundvall, who emphasized it as "the elements and relationships which interact in the production, diffusion and use of new, and economically useful, knowledge... and are either located within or rooted inside the borders of a nation state" [8]. The third main author in the field, R. Nelson, focused on the set-up of actors and the specifics of collaboration be-tween all of them [9].

Drawing on these scientific approaches, the main distinctions and commonalities of the concept of a national innovation system can be determined (See Table 1). 


\section{Comparative characteristics of the original versions of the concept of a national innovation system [5, p. 7]}

\begin{tabular}{|c|c|c|c|}
\hline \multirow{2}{*}{$\begin{array}{l}\text { Criteria of } \\
\text { comparison }\end{array}$} & \multicolumn{3}{|c|}{ The "fathers" of the concept of a national innovation system } \\
\hline & C. Freeman & B.-A. Lundvall & R. Nelson \\
\hline 1 & 2 & 3 & 4 \\
\hline $\begin{array}{l}\text { Term } \\
\text { "National" }\end{array}$ & Not explicitly defined. & $\begin{array}{l}\text { National differences } \\
\text { and boundaries } \\
\text { define the national } \\
\text { innovationsystem. }\end{array}$ & $\begin{array}{l}\text { National system } \\
\text { encompasses elements } \\
\text { and relationship, either } \\
\text { located within or rooted } \\
\text { inside the borders of the } \\
\text { nation state. }\end{array}$ \\
\hline $\begin{array}{l}\text { Term } \\
\text { "System" }\end{array}$ & Not explicitly defined. & $\begin{array}{l}\text { A set of institutional } \\
\text { actors that, together, } \\
\text { play the major role in } \\
\text { influencing innovative } \\
\text { performances. }\end{array}$ & $\begin{array}{l}\text { A system of innovation } \\
\text { is constituted } \\
\text { by elements and } \\
\text { relationships which } \\
\text { interact in the } \\
\text { production, diffusion } \\
\text { and use of new and } \\
\text { economically useful } \\
\text { knowledge. }\end{array}$ \\
\hline $\begin{array}{l}\text { Term } \\
\text { "Innovation" }\end{array}$ & $\begin{array}{l}\text { Continuing process } \\
\text { of technical change, } \\
\text { involving the } \\
\text { introduction of new } \\
\text { products and the new } \\
\text { ways of organizing } \\
\text { production, distribution } \\
\text { and marketing. }\end{array}$ & $\begin{array}{l}\text { The process by which } \\
\text { business entities master } \\
\text { and get into practice } \\
\text { product design and } \\
\text { manufacturing process } \\
\text { that are new to them. }\end{array}$ & $\begin{array}{l}\text { On-going process of } \\
\text { learning, searching and } \\
\text { exploring, which result } \\
\text { in new products, new } \\
\text { techniques, new forms } \\
\text { of organization and } \\
\text { new markets. }\end{array}$ \\
\hline $\begin{array}{l}\text { Analytical } \\
\text { framework }\end{array}$ & $\begin{array}{l}\text { Relationship between } \\
\text { technology, socio- } \\
\text { economic structures } \\
\text { and institutions. }\end{array}$ & $\begin{array}{l}\text { Linking institutional } \\
\text { arrangements } \\
\text { to technological } \\
\text { and economic } \\
\text { performances }\end{array}$ & $\begin{array}{l}\text { Interactive learning } \\
\text { anchored in the } \\
\text { production structure. } \\
\text { Institutional set-up } \\
\text { including "firm } \\
\text { strategy". } \\
\text { Modes of cooperation } \\
\text { and competition. }\end{array}$ \\
\hline $\begin{array}{l}\text { Elements of } \\
\text { the system } \\
\text { put forward }\end{array}$ & $\begin{array}{l}\text { Quantitative aspects: } \\
\text { long-term trends } \\
\text { in the growth and } \\
\text { distribution of the } \\
\text { national levels } \\
\text { of research and } \\
\text { development;. }\end{array}$ & $\begin{array}{l}\text { The allocation } \\
\text { of research and } \\
\text { development activity } \\
\text { and the sources of its } \\
\text { funding. } \\
\text { The characteristics of } \\
\text { business entities }\end{array}$ & $\begin{array}{l}\text { The internal } \\
\text { organization of firms. } \\
\text { Inter-firm relationships. } \\
\text { Role of the public } \\
\text { sector. } \\
\text { Institutional set-up of } \\
\text { the financial sector of }\end{array}$ \\
\hline
\end{tabular}


National innovation system development: evidence from the countries of...

Ending of Table 1

\begin{tabular}{|c|c|c|c|}
\hline 1 & 2 & 3 & 4 \\
\hline $\begin{array}{l}\text { Elements of } \\
\text { the system } \\
\text { put forward }\end{array}$ & $\begin{array}{l}\text { comparison of the } \\
\text { indicators of science } \\
\text { and technology at } \\
\text { disaggregated level; } \\
\text { the relationship } \\
\text { between these } \\
\text { indicators and } \\
\text { measures of economic } \\
\text { performances. } \\
\text { Qualitative aspects: } \\
\text { the role of the } \\
\text { company research and } \\
\text { development strategy } \\
\text { in relation to imported } \\
\text { technology and reverse } \\
\text { engineering; } \\
\text { the role of education } \\
\text { and training and } \\
\text { related social } \\
\text { innovations; } \\
\text { the conglomerate } \\
\text { structure of industry. } \\
\end{array}$ & $\begin{array}{l}\text { and the important } \\
\text { industries. } \\
\text { The role of universities } \\
\text { and government } \\
\text { laboratories. } \\
\text { Government policies } \\
\text { aimed at industrial } \\
\text { innovation. } \\
\text { Key interactions or } \\
\text { networks of actors. } \\
\text { Component and system } \\
\text { producers. } \\
\text { Upstream and } \\
\text { downstream firms. } \\
\text { Universities and } \\
\text { industry. } \\
\text { Government agencies, } \\
\text { university and industry. }\end{array}$ & $\begin{array}{l}\text { the economy. } \\
\text { Research and } \\
\text { development } \\
\text { organization. }\end{array}$ \\
\hline $\begin{array}{l}\text { Main } \\
\text { orientation }\end{array}$ & $\begin{array}{l}\text { To develop the } \\
\text { national innovation } \\
\text { system concept. }\end{array}$ & $\begin{array}{l}\text { To describe differences } \\
\text { and similarities } \\
\text { between national } \\
\text { systems and the } \\
\text { extent that these } \\
\text { differences explain } \\
\text { in national economic } \\
\text { performances. }\end{array}$ & $\begin{array}{l}\text { To provide a } \\
\text { theoretical perspective } \\
\text { that might be used in } \\
\text { case studies and to } \\
\text { discuss some important } \\
\text { subsystems. }\end{array}$ \\
\hline $\begin{array}{l}\text { Type of the } \\
\text { analysis }\end{array}$ & $\begin{array}{l}\text { Single case study } \\
\text { (Japan). }\end{array}$ & $\begin{array}{l}\text { Comparative case } \\
\text { study ( } 15 \text { countries } \\
\text { divided into large } \\
\text { high-income, small } \\
\text { high-income and low } \\
\text { income countries). }\end{array}$ & $\begin{array}{l}\text { Conceptual / } \\
\text { Theoretical analysis. }\end{array}$ \\
\hline
\end{tabular}

From the Table 1 it can be argued that the focus on the constituents of systems of innovation (institutions, organizations and interactions) is common to all three presented approaches to the definition of the concept of a national innovation system.

Since the 90s of the XX century, the given concept has attracted the attention of many researchers all over the world, as well as the policy-makers working 
on new architectures for the development of the knowledge-based economies. It is widely considered as one of the most important concepts to emerge in the field of innovation studies [10]. The national innovation system has proven to be "the national institutions, their incentive structures and their competencies, that determine the rate and direction of technological learning (or the volume and composition of change generating activities) in a country [11]. According to Balzat and Hanush (as cited by Santoned T., Kaivo-oja J. and Suomala J. [12]), a national innovation system is a historically grown subsystem of the national economy in which various organizations and institutions interact with and influence one another in the carrying out innovative activity.

On the basis of the above considerations, it's reasonable to assume that there is no single accepted definition of national innovation system. However, there is a semantic core that can be seen in most of the definitions, which is related to the major characteristics of the national innovation systems (See Table 1).

Table 2

\section{The characteristics of the national innovation systems [generalized by authors]}

\begin{tabular}{|l|l|}
\hline \multicolumn{1}{|c|}{$\begin{array}{c}\text { NIS major } \\
\text { characteristics }\end{array}$} & \multicolumn{1}{c|}{ Explanation } \\
\hline $\begin{array}{l}\text { The national } \\
\text { innovation system } \\
\text { is based on the } \\
\text { systemic approach }\end{array}$ & $\begin{array}{l}\text { Today the ideas for innovation can come from various sources. } \\
\text { They can also appear at any stage of the process of research, } \\
\text { development, marketing and diffusion. As a result, the systemic } \\
\text { approach is considered to be better for policy-makers, because of } \\
\text { its ability to identify leverage points and weak links within the } \\
\text { national innovation system. }\end{array}$ \\
\hline $\begin{array}{l}\text { Innovation is the } \\
\text { focus of any national } \\
\text { innovation system }\end{array}$ & $\begin{array}{l}\text { Innovation is the natural result of an interaction between different } \\
\text { actors and institutions of the national innovation system. }\end{array}$ \\
\hline $\begin{array}{l}\text { A flow of } \\
\text { knowledge } \\
\text { contributes to the } \\
\text { formation of the } \\
\text { national innovation } \\
\text { system }\end{array}$ & $\begin{array}{l}\text { There are many channels and mechanisms through which knowledge } \\
\text { can flow among the institutions of the national innovation system. } \\
\text { Actually, these flows are as follows: interactions among business } \\
\text { entities; interactions among business entities, universities and public } \\
\text { research laboratories; diffusion of knowledge and technology to the } \\
\text { enterprises; and personnel mobility. }\end{array}$ \\
\hline $\begin{array}{l}\text { NIS is the network } \\
\text { of the stakeholders } \\
\text { involved in } \\
\text { innovation } \\
\text { processes }\end{array}$ & $\begin{array}{l}\text { Business entities, public research institutes, universities, financial } \\
\text { institutions, educational system government regulatory bodies } \\
\text { and other actors are interdependence each other, but the linkages } \\
\text { among them are key to improving technology performance. }\end{array}$ \\
\hline
\end{tabular}


As we can observe from the Table 2, national innovation system is a set of interrelated institutions that produce, diffuse and adapt new technical knowledge. The links between these institutions consist of various flows: knowledge, financial, human, regulatory, and commercial. "As such, a national innovation system includes not just the institutions performing research and development and the level and sources of funding for such research and development, but also policies, such as antitrust policy, intellectual property rights and regulatory policy that affect technology development, the training of scientists and engineer, and technology adoption" [13].

The following paradigm traces the interaction of the national innovation system to innovation, investment and growth (See Figure 1).

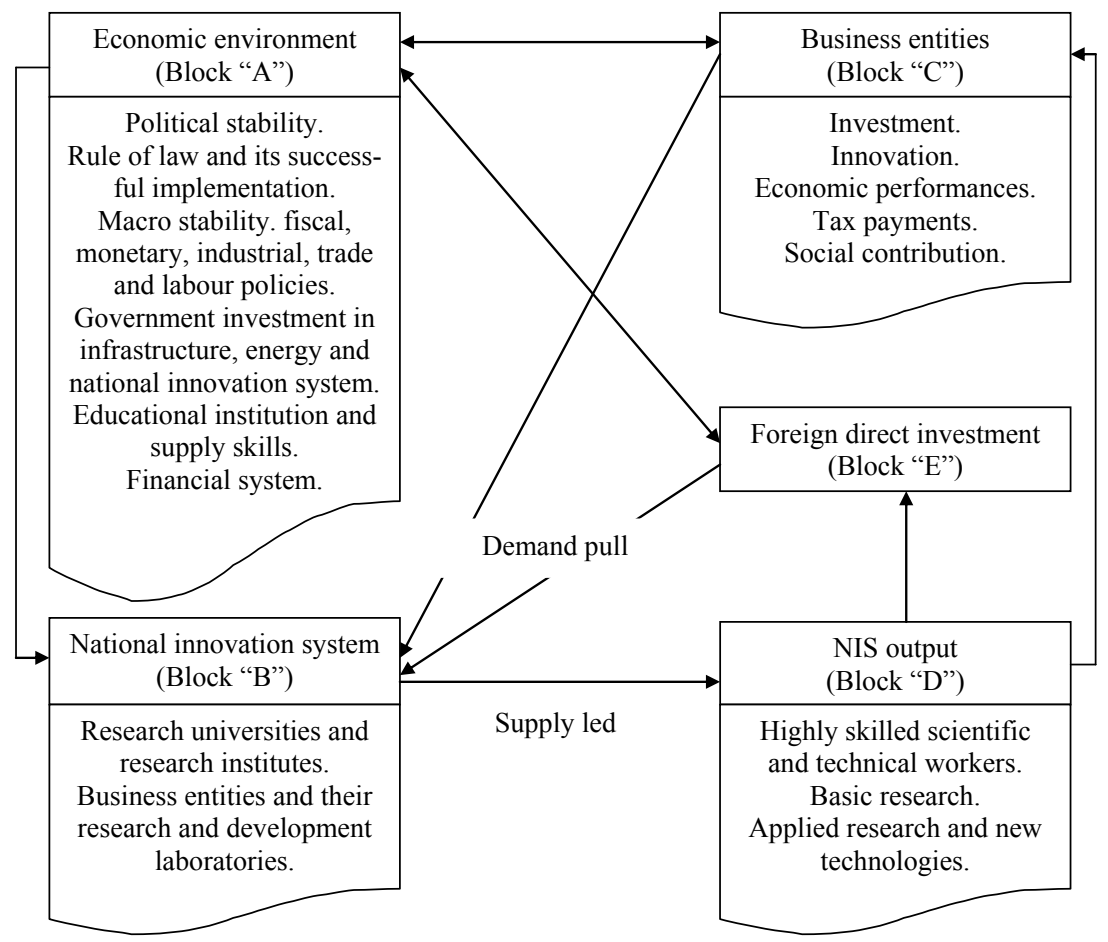

Fig. 1. A general framework of interaction between the national innovation system, economic environment and business entities [developed by authors] 
According to the Figure 1, block " $A$ " is related to the constraints or motives to investment and innovation. In other words, it consists of macro and political stability, as well as quality of labour and labour policy, quality of governance, financial system, trade and industrial policy, infrastructure etc. At the same time, block " $\mathrm{B}$ " is the national innovation system comprising of research and academic institutions that undertake research and development and contribute to the stock of knowledge and technology. On the contrary, block "C" shows NIS output only. As regards another block "D", it has the country's business entities as they are impacted by conditions in the previous blocks " $\mathrm{A}$ " and "B". Business decisions concerning the investment and innovation should be made in response to conditions determined in blocks "A" and "B" only.

It should be understood that these conditions may be not only favourable (able to stimulate business investment and innovation, which in turn create the demand for national innovation system services, employment opportunities for scientific and technical workers, and demand for advanced scientific and technical education), but also unfavourable ones.

Therefore, a national innovation system is an expected result of innovation process governance and knowledge resources management through an ap-propriate institutional set up and legal framework. The unprecedented increase in the ability of society to social and institutional change through such an institutional set-up ultimately points out the importance of socio-cultural factors of sustainable economic growth. In general, the concept of a national innovation system provides a tool for analysis of the specifics of any country in the global economy, as well as a guide for effective innovation policy formulation.

\section{Challenges facing the national innovation system development}

The European Union is a unique partnership in which member states have pooled sovereignty in certain policy areas and harmonized laws on a wide range of economic and political issues. Today the EU consists of 28 member states, including the formerly communist countries of Central and Eastern Europe [14].

The move towards globalization and regionalization - that has increased pace over the past decades - has had a strong influence on the driving forces and business landscape, which creates and shapes the strategic opportunities and re-quirements for economic development, growth, employment 


\section{National innovation system development: evidence from the countries of...}

levels, and social and environmental sustainability. The Central and Eastern European countries play an important role in the European region as emerging markets, competitive players in manufacturing and services, and political-economic actors. Compared to Western European states and business entities, those in the Central and Eastern Europe region receive limited and sporadic coverage in business literature, although the changing dynamics in the European region makes these a captivating academic subject, a high priority policy-making arena, and an important field for international business strategic decision makers [15, p. 10].

After the turbulent historical experience during the past decades, the process of convergence to Western Europe has delivered tangible results. According to the results of the investigations published in the Workshop report by the Joint Research Centre [16, p. 6], the Central European countries (like Slovenia, the Czech Republic and the Slovak Republic) are exhibiting average performance measures three to four times higher than other countries, like Ukraine, Georgia and Moldova (See Table 3).

On the basis of the data from Table 1 it should be mentioned that the countries from that region that are Members of the European Union, exhibit more than double the income per capita from other, non-EU member countries, on average. The process of convergence is also multifaceted: for countries of this region, membership to the EU is associated with an increase of $14 \%$ in the Human Development Index. In such a diverse landscape, fostering a data-driven economy through the capacity of a public open-data infrastructure addresses key concerns of the region regarding growth and development [16, p. 7].

Despite the efforts carried out to restore economic dynamism through macroeconomic interventions and structural reforms, growth expectations remain tempered across those Central and Eastern Europe economies, where growth rates remain low and unemployment stubbornly high. These countries continue their struggle to increase the level of the competitiveness and to set the national economy on a more solid footing.

Taking into consideration the nature of the national innovation concept, Central and Eastern European economies face several challenges in the race to innovation, which derive from inefficient governance, weak infrastructure and poor quality of the business environment.

Thus, for instance, inefficient governance means that today there are only a very few developing countries in the Central and Eastern Europe 
Table 3

The main Development Indices of the countries in the Central and Eastern Europe region, 2016 [16, p. 7]

\begin{tabular}{|c|c|c|c|c|c|}
\hline Countries & $\begin{array}{c}\text { European } \\
\text { Union }\end{array}$ & OECD & $\begin{array}{c}\text { Gross } \\
\text { national } \\
\text { Income } \\
\text { per capita } \\
\text { (2016) }\end{array}$ & $\begin{array}{c}\text { Human } \\
\text { Development } \\
\text { Index }\end{array}$ & $\begin{array}{c}\text { Time } \\
\text { Required } \\
\text { to Register } \\
\text { Property } \\
\text { (days) }\end{array}$ \\
\hline 1 & 2 & 3 & 4 & 5 & 6 \\
\hline Slovenia & $\mathrm{x}$ & $\mathrm{x}$ & 28,664 & 0,89 & 50 \\
\hline Czech Republic & $\mathrm{x}$ & $\mathrm{x}$ & 28,144 & 0,88 & 28 \\
\hline Slovak Republic & $\mathrm{x}$ & $\mathrm{x}$ & 26,764 & 0,84 & 17 \\
\hline Estonia & $\mathrm{x}$ & $\mathrm{x}$ & 26,362 & 0,87 & 18 \\
\hline Poland & $\mathrm{x}$ & $\mathrm{x}$ & 24,117 & 0,86 & 33 \\
\hline Hungary & $\mathrm{x}$ & $\mathrm{x}$ & 23,394 & 0,84 & 18 \\
\hline Latvia & $\mathrm{x}$ & $\mathrm{x}$ & 22,589 & 0,83 & 17 \\
\hline 1 & 2 & 3 & 4 & 5 & 6 \\
\hline Lithuania & $\mathrm{x}$ & & 26,006 & 0,85 & 4 \\
\hline Croatia & $\mathrm{x}$ & & 20,291 & 0,83 & 62 \\
\hline Romania & $\mathrm{x}$ & & 19,428 & 0,80 & 16 \\
\hline Bulgaria & $\mathrm{x}$ & & 16,261 & 0,79 & 19 \\
\hline Montenegro & & & 15,410 & 0,81 & 69 \\
\hline Macedonia & & & 12,405 & 0,75 & 30 \\
\hline Serbia & & & 12,202 & 0,78 & 21 \\
\hline Albania & & & 10,252 & 0,76 & 19 \\
\hline $\begin{array}{l}\text { Bosnia \& } \\
\text { Herzegovina }\end{array}$ & & & 10,091 & 0,75 & 24 \\
\hline Georgia & & & 8,856 & 0,77 & 1 \\
\hline Ukraine & & & 7,361 & 0,74 & 17 \\
\hline Moldova & & & 5,026 & 0,70 & 8 \\
\hline
\end{tabular}

region, that have their own effective innovation strategies or strong innovation policies.

As regards to another challenge in the race to innovation, it should be men-tioned that there is the lack of technological support services and infrastructure (i.e. quality control, quality standards and metrology) in the Central and Eastern Europe economies. That is why not only telecommunications, but also road and other transport infrastructure, sanitation, water and other systems should be of priority importance in the near future. 
Additionally, an equally important problem of innovation engagement in the countries of the Central and Eastern Europe region is concerned with the poor quality of the business environment. This means that in many national economies of the region, chosen for research, formal rules and laws are less developed, and their further enforcement tends to be unreliable and arbitrary. Thus, it is no wonder that the results of such intervention do not stimulate the desired innovative behavior across the country as a whole.

\section{Implementation of an integrated innovation approach: lessons for Ukraine}

One of the important lessons of the past two decades has been the pivotal role of innovation in economic development. The build-up of innovation capacities has played a central role in the growth dynamics of successful developing countries all over the world (See Table 4).

As we can observe from the Table 4, the majority of countries have recognized that innovation is not just about high-technology products and that the national innovation capacity has to be created in the development process in order to possess the learning capacities that will allow "catch up" to happen. Many countries all over the world also need innovation capacity and local innovations to address challenges specific to their local contexts [15].

The future growth of Central and Eastern Europe greatly depends on upgrading technology, exporting and coupling domestic technology efforts while improving their position in global value chains. Current policies in the region are not geared to these tasks, despite the availability of huge financial opportunities in the form of EU structural funds. Existing policies are overly focused on research and development, as well as the neglect sources of productivity growth, such as management practices, skills, quality, and engineering. The challenge is how to design industrial and innovation policies so that they promote modernization and drive structural change [17].

The concept of an effective national innovation system in the countries of Central and Eastern Europe region should be more complex because it consists of the limited types of formal sector actors (enterprises, universities, research institutes, government and financial system bodies) and informal sector actors (various non-governmental organizations and informal companies). Therefore, the main problems in the governance of such an 


\begin{tabular}{|c|c|c|}
\hline \multicolumn{3}{|c|}{$\begin{array}{c}\text { The explanation of the importance of innovation initiatives } \\
\text { for developing and emerging countries } \\
\text { [developed by authors on the basis of the source: 15] }\end{array}$} \\
\hline $\begin{array}{l}\text { Country } \\
\text { category }\end{array}$ & Objective of innovation & Main agents involved \\
\hline 1 & 2 & 3 \\
\hline \multirow[t]{2}{*}{$\begin{array}{l}\text { Developing / low- } \\
\text { income countries } \\
\text { and emerging and } \\
\text { middle income } \\
\text { countries }\end{array}$} & $\begin{array}{l}\text { Adoption requires } \\
\text { adaptation: Innovation } \\
\text { needs to respond to specific } \\
\text { "local" conditions for } \\
\text { outcomes. }\end{array}$ & $\begin{array}{l}\text { Universities and research institutes, } \\
\text { leading private businesses, } \\
\text { especially those with exposure to } \\
\text { foreign markets and businesses }\end{array}$ \\
\hline & $\begin{array}{l}\text { Inclusive innovation: for / } \\
\text { by low- and middle income } \\
\text { households to improve } \\
\text { welfare and access to } \\
\text { business opportunities. }\end{array}$ & $\begin{array}{l}\text { Non-governmental organizations, } \\
\text { small enterprises, public and } \\
\text { private associations engaged in } \\
\text { disseminating knowledge via } \\
\text { networks, private, often large } \\
\text { businesses. }\end{array}$ \\
\hline \multirow[t]{3}{*}{$\begin{array}{l}\text { Mainly middle- } \\
\text { income countries, } \\
\text { but also some } \\
\text { opportunities for } \\
\text { developing / low- } \\
\text { income countries }\end{array}$} & $\begin{array}{l}\text { Build up innovation } \\
\text { capacities that will be key } \\
\text { for reaching the world } \\
\text { technological frontier } \\
\text { in many industries, esp. } \\
\text { relevant to avoid "middle- } \\
\text { income traps". }\end{array}$ & $\begin{array}{l}\text { Requires full development of } \\
\text { innovation systems involving } \\
\text { diasporas as a connector. }\end{array}$ \\
\hline & $\begin{array}{l}\text { Address environmental, } \\
\text { health and social challenges } \\
\text { through global innovation } \\
\text { efforts and local efforts to } \\
\text { address them }\end{array}$ & $\begin{array}{l}\text { Public and private universities and } \\
\text { research institutions connected to } \\
\text { global networks but also major } \\
\text { private businesses operating in } \\
\text { these sectors }\end{array}$ \\
\hline & $\begin{array}{l}\text { Build-up niche } \\
\text { competencies, i.e. growth } \\
\text { / exports in sectors of } \\
\text { comparative advantage } \\
\end{array}$ & $\begin{array}{l}\text { Public institutions to address } \\
\text { coordination challenges, private } \\
\text { sector initiative including foreign } \\
\text { companies. }\end{array}$ \\
\hline \multirow[t]{2}{*}{$\begin{array}{l}\text { Mainly emerging } \\
\text { / middle-income } \\
\text { countries after } \\
\text { initial progress on } \\
\text { dimensions above }\end{array}$} & $\begin{array}{l}\text { Climb the value ladder in } \\
\text { global value chains }\end{array}$ & $\begin{array}{l}\text { Private sectors with support from } \\
\text { public agents, intermediaries, } \\
\text { diasporas can play a central role, } \\
\text { large firms can be important. }\end{array}$ \\
\hline & $\begin{array}{l}\text { Keep competitiveness in } \\
\text { frontier industries when the } \\
\text { country is already at the } \\
\text { frontier }\end{array}$ & $\begin{array}{l}\text { Mainly private sector in } \\
\text { interaction with public research } \\
\text { institutions and universities, global } \\
\text { partnerships often equally of } \\
\text { relevance, role of large firms. }\end{array}$ \\
\hline
\end{tabular}


innovation system are to meet the needs of both above-mentioned sectors of the economy.

Within the present study we consider it appropriate to describe the core principles of the integrated approach in promoting innovations (See Figure 2), which is used in the countries of the Central and Eastern Europe region.

Creating a financial system for Innovation

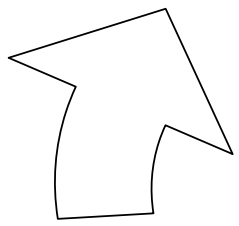

The creation of science parks and technology business incubators
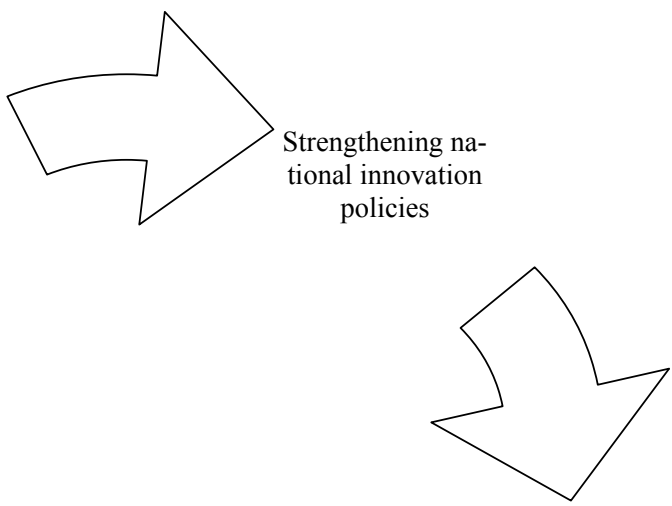

Improving research and development capacities

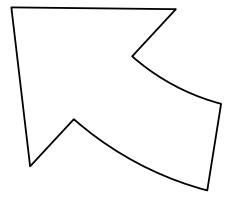

Enhancing the innovation capacity of business entities

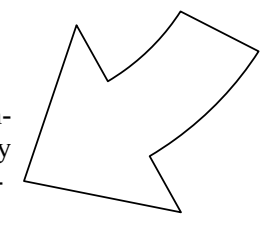

Fig. 2. The core principles of an integrated approach in promoting innovative initiatives in the Central and Eastern European countries [developed by authors]

As we can see from the Figure 2, the first principle or idea of an integrated approach in promoting innovations is related to strengthening national innovation policies. The countries of the Central and Eastern Europe region need to set up the existing innovation policies with the main priorities that are based on certain challenges and opportunities faced by each country 
concerning innovation. "Innovation policy is defined as public intervention to support the generation and diffusion of new products, processes or services" [18]. Rather, it addresses specific problems of the national innovation system, such as the rules of its functioning and regulations able to ensure competition level experience and allow financial markets to provide the necessary signals to investors. To move towards achieving a desired type of innovation policy and its further implementation, broad-based societal participation is required. In this context, state government decision makers, as well as entrepreneurs, researchers and representatives of non-governmental organizations, are fairly considered to be the main agents of change of the existing innovation systems.

Another core principle of the integrated approach in promoting innovative initiatives is related to the improving of the research and development capacities. Research and development activities in the countries of the Central and Eastern Europe still remains very low. It can be explained by the fact of the low investment in this field. In order to improve the existing research systems, the countries of this region should increase their investment in building human resources capacity of and research infrastructure improvement. Innovation and capacity building in most countries covered by this research would benefit from upgrading the skills of workers and training more skilled workers and technicians. This priority can be realized not only by formal education and training, but also by diffusing the concept of learning organizations among business entities; the diffusion should function as heuristic device for local enterprises' experimentation within specific context of learning organizational form. Universities and other higher educational institutions are considered to be the key players in the process of national innovation system development. Universities located in the Central and Eastern Europe region, like in many other regions in the world, successfully produce welltrained human resources and conduct research able to generate knowledge for innovation. Obviously, each of these higher educational institutions already have the considerable intellectual capital that can be deployed to work on the solution of the problem of national innovation system development. Therefore, the universities of the Central and Eastern Europe region should play an important role in dealing with social, economic and environmental challenges. For example, in many countries of this region there is a great opportunity for universities and research centres only to conduct research and development in order to support the important innovation initiatives and to 


\section{National innovation system development: evidence from the countries of...}

develop technology business incubators and science parks to host small and medium enterprises (SMEs).

The next principle of the integrated approach in promoting innovative initiatives is concerned with enhancing the innovation capacity of enterprises. In this regard it should be noted that the given approach is needed to enhance the innovation capacities of business entities in the countries of the Central and Eastern region. Consequently, the approach should take into consideration the multifaceted nature of the existing business entities. Engaging in interactive learning with other actors of the national innovation system is fundamental for development of innovation initiatives.

Equally important is another principle of an integrated approach in promoting innovation initiative, which is related to supporting the creation of knowledge-based small and medium enterprises: science parks and technology business incubators. In modern society the aim of business incubation is to increase the success ratio of start-up enterprises even if the incubator is not a definitive place for the SMEs. The graduated start-up enterprises must relocate to a certain science park. The existence of these business structures is very important to facilitate networking for innovation in the countries of Central and Eastern Europe. Science parks should be particularly interested in enhancing the innovative capacity and foster the enterprises through ensuring and effective interaction and close relationship between government bodies, research and development centres, various research institutes, high-tech industry, launching commercialization and providing financial support. In the present-day context science and technology parks play a significant role in advancement of the in-formation and communication technology, bio- and nanotechnology, electronics and other fields of technology. Many Central and Eastern European economies have also taken the initiative in science parks and incubators development. Nevertheless, most of them are faced with the following problems: low successful rate of incubator tenants, rather slow advancement of innovation, etc. The technology business incubators and science parks in the Central and Eastern European economies should not only host hi-tech start-up enterprises, but also accommodate low-tech start-ups too.

And, finally, the last principle of an integrated approach in promoting innovative initiatives is nothing other than the creation of a financial system for innovation. As we know, in the OECD member countries, thousands of venture capital funds successfully operate to finance knowledge-based 
start-up enterprises. Thus, the aim of the venture capital investor is to invest in rapidly growing business entities in order to sell out, either to another entrepreneur, or the stock market. However, the unreasonably high risk of this type of investment is covered by the high return on successful ventures. Unfortunately such financial systems do not exist in most Central and Eastern Europe economies. Financial institutions are not interested in investing in start-ups because of the complete absence of guarantees and the existence of high risks. However, it is important to establish an existing financial system to support knowledge-based start-ups in the Central and Eastern Europe region.

In general, Central and Eastern European economies do not grow based on research-driven innovation whereby domestic research produces innovation that leads to growth; instead, they rely on the interaction of domestic research and development with more advanced technology from imported equipment and inputs. However, this situation is not reflected in policy, which is geared solely toward the traditional idea of research-driven growth. Central and Eastern European countries would hence be better served by enacting policy that encourages improvements in production capability. This, in turn, would generate demand for local research and development and innovation, which is currently lacking.

In the authors' opinion, the implementation of this approach is expedient in Ukraine. As regard to this country, it should be emphasized that it significantly lags behind the developed countries of the Central and Eastern Europe by the level of innovation economy development. The direct statistical comparison between Ukraine and the countries of Central and Eastern European region is rather difficult. Not all innovation financing related data is available from Ukraine, or it is sometimes not fully comparable with those European countries.

On the one hand, there are low indexes of competitiveness of the national economy and the readiness of Ukraine to function in the global market. On the other hand, in many fields of scientific research and innovation the priority positions of the country remain competitive. However, the implementation of these opportunities is greatly influenced by the national innovation policy specifics and the choice of a single vector of Ukraine's international integration and increasing participation in international scientific and technical collaboration with the world's most leading countries. That is why European integration should be considered as an effective tool to increase economic development of Ukraine and to develop its innovation system. 


\section{National innovation system development: evidence from the countries of...}

\section{Conclusions}

Through this research we have come to certain conclusions.

The concept of the national innovation system first appeared in the $80 \mathrm{~s}$ of the XX century in the framework of institutional and evolutionary economists (C. Freeman, B.-A. Lundwall and R. Nelson) with the main aim to understand and put into action the process through which scientific research and knowledge is produced and transferred into business and innovation.

"The Organization for Economic Cooperation and Development (OECD) provides only one framework for detailing a country's national innovation system, suggesting primary roles for institutional actors. This framework includes as follows: performing research and development, financing research and development, human resource development, diffusing technology, promoting entrepreneurship, and formulating technology and innovation policy" [19]. This broad definition encompasses everything from administrative agencies and conducting public research, private-sector research business entities, higher education and bridging institutions.

The two main features of a certain national innovation system ground for its huge influence on government practices for improving the national competitiveness and economic growth. First of all, national innovation system provides a peculiar "recipe" to national governments on how to cope with globalized innovation-based competition. Such a recipe consists of certain recommendation to governments to establish an institutional set up of private and public institutions that would accelerate creation, storage and transfer the knowledge and skills which produces new technologies and innovation. It calls for public policy induced interaction among sectors and intersectoral knowledge flow.

The second appealing feature of a national innovation system comes from its underlying message that economic growth is not an economic spontaneous process simply driven by the "hidden hand" of market which is beyond the reach of socio-economic entities. Besides, competitiveness of a country in the global chessboard does not depend on the scale of research and development but rather upon the way in which the available resources are managed and organized, both at the micro- and macro level.

Current innovation system of Ukraine is fragmented. It is characterized by poor business environment, a very limited research community, low education levels, weak infrastructure, inefficient public institutions, inefficient governance etc. The implementation of the concepts of national innovation 
system development widely used in other countries needs to be done carefully, by taking into consideration of the local conditions.

By the way, an innovation system, which can accommodate the interaction among the high varieties of stakeholders, such as enterprises, universities, re-search institutes and government, financial system, non-governmental organizations, informal companies must be developed. An integrated approach is needed to establish an appropriate innovation system in Ukraine. An innovation system which is based on relevant innovation policies, able to accommodate innovations, involves the formal and informal sector of the economy and that aims to improve the quality life.

The results obtained during this study can be used as a basis for further practical applications, potentially leading to new management capabilities of national innovation systems. We have found that the ability of the country to manage the quality of its own institutional capital and its interaction with other components of the national innovation system is a key factor of successful innovation in the conditions of globalization. The transformation of infrastructural capacities into effectively functioning human, research, market, and business constituents of national innovation systems is entirely determined by institutional capital and is significantly affected by the innovation output of a country.

\section{References:}

1. Asia to overtake US and Europe in innovation centers. (2017). [Electronic resource].-Retrieved from: http://www.thenextsiliconvalley.com/2017/01/07/4876asia-to-overtake-us-and-europe-in-innovation-centers/

2. State of the Innovation Union 2011. Report from the Commission to the European Parliament, the Council, the European Economic and Social Committee and the Committee of the Region [Electronic Resource]. - Retrieved from: https://ec.europa.eu/research/innovation-union/pdf/state-of-the-union/2011/state of_the_innovation_union_2011_brochure_en.pdf

3. European Competitiveness and Industry 2017: Benchmarking [Electronic resource]. - Retrieved from: http://ert-industry-benchmarking.eu/wp-content/ uploads/2017/12/ERT-Stats_Benchmarking-2017_4web_21122017hyperlinksgrou pedBookmarks.pdf

4. Bieńkowska E., Moedas C. (2017). European Innovation Scoreboard 2017 [Electronic resource]. - Retrieved from: https://www.rvo.nl/sites/default/ files/2017/06/European_Innovation_Scoreboard_2017.pdf

5. Godinho M.M., Mendonça S.F. Towards a taxonomy of innovation systems [Electronic resource] - Retrieved from: http://pascal.iseg.utl.pt/ depeco/wp/ wp132005.pdf 


\section{National innovation system development: evidence from the countries of...}

6. Ramanathan K. The concept and role of a national innovation system (NIS) in national development [Electronic resource]. - Retrieved from: http://apctt.org/ nis/sites/all/themes/nis/pdf/CSNWorkshop_Report P2S1 Ramanathan.pdf

7. Freeman C. (1987). Technology policy and economic performance: Lessons from Japan. London: Pinter Publishers.

8. Lundvall B.-A. (1992) National systems of innovation. London: Anthem Press.

9. Nelson R. (1993) National Innovation Systems. New York: Oxford University Press.

10. Schrempf B., Kaplan D., Schroeder D. (2013). National, regional and sectoral systems of innovation - An overview. Report for FP7 Project "Progress" [Electronic resource]. - Retrieved from: http://www.progressproject.eu/wp-content/uploads/2013/12/Progress D2.2 final.pdf

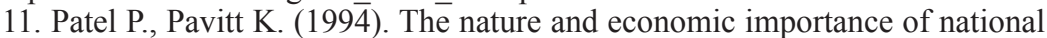
innovation systems. STI Review. No. 14. OECD, Paris.

12. Santonen T., Kaivo-oja J., Suomala J. (2007). Introduction to national open innovation system paradigm. A preliminary concept for interchange [Electronic resource]. - Retrieved from: https://www.utu.fi/fi/yksikot/ffrc/julkaisut/e-tutu/ Documents/eTutu_2007-8.pdf

13. Laredo P., Mustar P. Research and innovative policies in the new global economy [Electronic resource]. - Retrieved from: http://ifris.org/wp-content/blogs. dir/1/files/2014/10/35. -Chap._01_and_14.pdf

14. Archick K. The European Union: Current Challenges and Future Prospects [Electronic resource]. - Retrieved from: https://fas.org/sgp/crs/row/R44249.pdf

15. Myszkowska M. (2015). The competitiveness landscape in Central and Eastern Europe. Economic of the 21st century, Vol. 4 (8), pp. 9-19.

16. Kotsev A., Cetl V., Dusart J., Mavridis D. (2018). Data-driven economies in Central and Eastern Europe: Challenges and Prospects. Joint Research Centre Conference and Workshop Reports [Electronic resource]. - Retrieved from: http://publications.jrc.ec.europa.eu/repository/bitstream/JRC110525/workshop proceeding dataeconomy paper online.pdf

17. Radosevic S. Upgrading technology in Central and Eastern European economies: Existing policies in Eastern Europe will not sufficiently promote technological innovation [Electronic resource]. - Retrieved from: https://wol.iza.org/uploads/ articles/338/pdfs/upgrading-technology-in-central-and-eastern-european-economies.one-pager.pdf

18. Elder J., Cunningham P., Gök A., Shapira P. (2013). Impacts of innovation policy: synthesis and conclusions. Compendium of evidence on the effectiveness of innovation policy intervention project. Manchester Institute of Innovation Research [Electronic resource]. - Retrieved from: http:/www.innovation-policy.org.uk/ share $/ 20$ Impacts $\% 20$ of $\% 20$ Innovation $\% 20$ Policy $\% 20$ Synthesis $\% 20$ and $\% 20$ Conclusion_linked.pdf

19. Chē S.W. (2010). Comparison of national innovation systems in China, Taiwan and Singapoure: Is Bayh Dole one size that fits all? AUTM Technology Transfer Practice Manual. Electronic resource]. - Retrieved from: https://www.autm.net/AUTMMain/media/ThirdEditionPDFs/V4/TTP_V4 AsianNIS.pdf 